Article

\title{
Does Employees' Participation in Decision Making Increase the level of Corporate Social and Environmental Sustainability? An Investigation in South Asia
}

\author{
Omer Farooq $^{1, *}$, Mariam Farooq ${ }^{2}$ and Emmanuelle Reynaud ${ }^{3}$ \\ College of Business and Economics, UAE University, Al Ain, UAE \\ 2 UCP Business School, Uniersity of Central Pujab, Lahore 54000, Pakistan; farooqmariam82@gmail.com \\ 3 CERGAM, IAE-Aix en Provence, University of Aix-Marseille, Puyricard, 13540 Aix en Provence, France; \\ Emmanuelle.reynaud@iae-aix.com \\ * Correspondence: omer@uaeu.ac.ae; Tel.: +97-154-362-8800
}

Received: 9 November 2018; Accepted: 14 January 2019; Published: 18 January 2019

check for updates

\begin{abstract}
Although previous studies have explored the role of legal framework, industry norms, innovation, and the use of clean technologies to achieve sustainability, they have paid little attention to the role of employees in increasing a firm's sustainability performance. This article develops a model based on social identity theory and proposes that employees whose organizational identification is rooted in the sustainability of the firm can influence the sustainability strategy of the firm through the participation process. Data were obtained from 421 employees of large fast-moving consumer goods manufacturers. The findings demonstrate that employee participation has a strong positive effect on all the components of sustainability (environmental and societal). Moreover, the findings show that the impact of employee participation on the components of sustainability is moderated by organizational identification in such a way that if employees have a strong sense of identification with their organization, their participation in decision making has a greater impact on the sustainability of their organization.
\end{abstract}

Keywords: corporate sustainability; environmental sustainability practices; societal sustainability practices; employees' participation in decision making; South Asia

\section{Introduction}

Sustainability-commonly defined as a triple bottom line of environmental, social, and economic performance-has become increasingly popular in the field of management. Although companies struggle to embed environmental, social, and economic goals into their business strategies, this objective has not yet been fully realized $[1,2]$. Thus, corporate sustainability has become the center of attention for many management scholars and business managers. Several studies, e.g., [1-6], have explored the role of the firm's strategy, legal framework, industry norms, innovation, pollution prevention, and clean technologies in achieving corporate sustainability. Although these studies provide useful insight into corporate sustainability issues, scholars have paid little attention to the role of employees in increasing the firm's sustainability performance. The role of human resource management (HRM) in integrating the triple bottom line is also an understudied area [7]. We argue that conventional human resource (HR) practices are developed to support the traditional business paradigm of achieving maximum profit, so the HR function may not be congruent with the firm's sustainability goals. Therefore, firms must adopt new HR practices that are consistent with sustainability [8] and help the firm embrace sustainability principles. The current study attempts to 
explore HR practices that are essential for integrating the triple bottom line into firms' strategies and that help firms achieve their sustainability goals.

The literature demonstrates that HR practices are an important component that can help an organization become more effective in achieving its financial goals $[9,10]$. We argue that HR practices are not only vital for the economic bottom line of financial performance but also critical for the social and environmental bottom lines of sustainability. For example, Ramus and Steger [11] demonstrated that perceived organizational and supervisory support positively influence employees' eco-initiatives.

Relying on social identity theory, we suggest that employee participation in decision making (EPDM) is a means to enhance the sustainability of firms, particularly if employees have a high level of identification with their company. Recent research has shown that a company's socially responsible image increases employees' sense of identification with the company [12-17]. As such, we expect that employees can have a strong, positive influence on a company's sustainability-related decisions, and ultimately performance, through the participation process.

This study contributes to the literature in several ways. We believe that this study significantly contributes to an under-researched topic by examining the role of employee participation in the sustainability of the firm. This study also underscores the role of employees' organizational identification (OI) in achieving the firm's sustainability goals. In addition, we develop an instrument to assess corporate sustainability on the basis of an extensive literature review, and we test its validity and reliability using confirmatory factor analysis. Whereas most academic work on sustainability focuses on industrialized countries, this study shifts the lens to the developing world. Most of the available studies on corporate sustainability are set in a Western context. As such, the findings of these studies may not be applicable to South Asian organizations due to the vast differences in the economic, social, and cultural environments [18]. This region differs from the West insofar as it reflects a highly collectivist culture. People in a collectivist culture tend to have stronger group identity due to stronger in-group ties [19]. For this reason, an analysis of employee OI and participation in a firm's corporate sustainability efforts in a South Asian context has the potential to open up new avenues in the field of corporate sustainability and HRM.

\section{Corporate Sustainability}

Although there is no specific, consensus definition of corporate sustainability [20]-it means different things to different people [21] — it is often defined in terms of the triple bottom line of economic development, environmental quality, and social well-being [1], or profit, planet, and people [1]. Corporate sustainability is often synonymous with corporate social responsibility (CSR) [20-22], or the 'activities, decisions, or policies, that organizations engage in to effect positive social change and environmental sustainability' [23]. Although corporate sustainability is defined in terms of the people, planet, and profit triple bottom line, most analyses of sustainability do not include profit as an integral part of sustainability, e.g., [24,25]. Likewise, in this study, we only focus on the people and planet dimensions (see also Matten and Moon [26] and McWilliams and Siegal [27]). As Matten and Moon [26] suggest, 'CSR is differentiated from the business fulfillment of core profit-making responsibility and from the social responsibilities of the government'.

We also further divide the people dimension into insiders and outsiders [28], with insiders being the employees and outsiders being the community. Thus, we have three components of corporate sustainability, excluding profit: the community, the environment, and the employees. We term these components environmental sustainability practices (ESPs), societal sustainability practices (SSPs), and HR sustainability practices (HRSPs), respectively. Next, we discuss these three dimensions in greater detail.

\subsection{Environmental Sustainability Practices (ESPs)}

Environmental sustainability practices are the firm's actions, policies, and decisions with regard to improving the quality of the natural environment [29]. An environmentally responsible firm is 
concerned about the protection of the natural environment. It participates in activities that aim to protect and improve the quality of the natural environment. Such firms not only invest money in and take initiative to improve their environment practices at the firm level but also launch campaigns in the community to promote environmental protection [1].

\subsection{Societal Sustainability Practices (SSPS)}

Societal sustainability practices represent the community dimension of corporate sustainability; they comprise the firm's initiatives, policies, and decisions that affect the overall welfare of the community. The business activities of a societally sustainable firm need to demonstrate a deep concern for the general well-being of the community [30]. The firm needs to support the community's development by financing social and cultural activities [30,31]. Often, this includes giving substantial contributions to charities involved in the region; involving the community by encouraging collaboration with local people, nongovernmental organizations, and other local institutions; and respecting the social and cultural values of the community $[1,5,6]$.

\subsection{HR Sustainability Practices (HRSPs)}

Human resource sustainability practices are the set of HR practices that focus on employees overall well-being. The traditional HR paradigm emphasizes efficiency in HR systems, client satisfaction, and the effectiveness of HR programs in enhancing employees' characteristics that are relevant to the firm's financial performance [8]. In contrast, the sustainability paradigm focuses on the quality of work life and the overall well-being of employees, the regeneration and development of human resources, and the promotion of societal and environmental responsibility among employees. We gathered insight from the International Labour Organization declaration, the United Nations Global Compact, Agenda 21, and the relevant literature on CSR to identify the following eight HRSPs: (1) training and career development, (2) job security, (3) work-life balance, (4) flexible working hours, (5) employee voluntarism, (6) performance appraisal on employee social and environmental performance, (7) health care, and (8) justice and equity.

\section{Hypotheses}

We propose that employees' participation in decision making positively influences the firm's sustainability practices and that employees' OI positively moderates this relationship. We depict the research model in Figure 1.

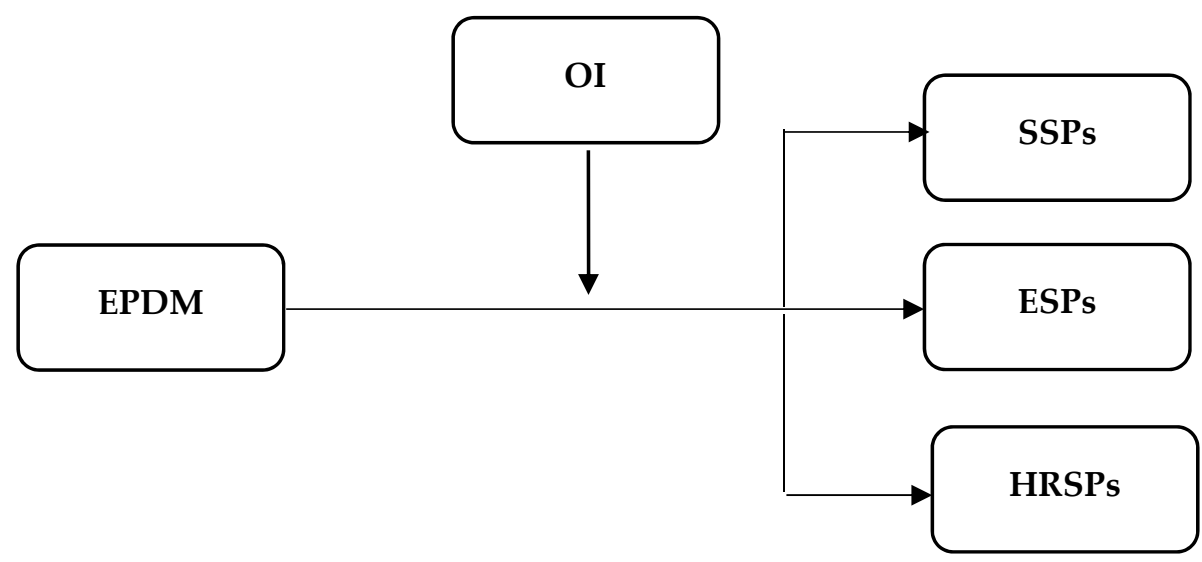

Figure 1. Theoretical research model. Note: EPDM: Employees Participation in Decision Making; OI: Organizational Identification; SSPs: Societal Sustainability Practices; ESP: Environmental Sustainability Practices; HRSPs: Human Resources Sustainability Practices.

Social identity theory demonstrates that people strive to enhance and maintain a positive social identity [32-34], which they derive from membership in different groups [33]. Hogg and Terry [35] 
illustrate that of the various groups to which people belong, membership in the business organization is the most important component of employees' social identity; this is termed organizational identification, or OI-the 'perception of oneness with or belongingness to an organization, where the individual defines him or herself in terms of the organization(s) in which he or she is a member' [36].

Because employees derive a significant part of their social identity from membership in their work organizations, they are usually very conscious and sensitive to the status-related issues of the work groups and organizations to which they belong [37], and this motivates them to exert effort within these groups and organizations to strengthen their distinctive and prestigious identity [38,39]. For example, 'an individual who feels a strong affiliation with an environmental activist group, such as Greenpeace, will reinforce his or her identity as an environmentally conscious person by repeated participation in the group's activities' [38]. It means that people's desire to be identified with a particular kind of character, which is usually distinctive and prestigious, not only compels them to become attached to a group reflecting that character but also motivates them to struggle to enhance that particular group identity. Our argument is also supported by the work of Ashforth and Mael [33], who illustrated that 'social identification will reinforce the very antecedents of identification, including the distinctiveness of the group's values and practices, group prestige, salience and competition with out-groups and the traditional causes of the group formation'. Recent research has shown that a company's socially responsible and sustainability-related actions enhance the corporate image and outsiders' perceptions of the firm [40-42]. Because employees build their social identity from the reputation of their organization, they may compare the sustainability-related performance of their organizations with that of other firms and therefore actively work to maintain and enhance the distinctiveness and prestige of their organization's corporate sustainability.

Although employees may work to improve the level of sustainability in their organization, they are not likely to influence their firm's overall sustainability strategy without being able to participate in related organizational decision-making processes. Participation is defined as the amount of influence that employees have over decisions in the company [43]. Employees' participation in decision making means that they are being asked by their superiors to participate in the decision-making process, they are allowed to make some decisions themselves, they are given opportunities to suggest improvements in the way things are done, and there is open communication between supervisors and employees [44, 45]. Participation increases the overall influence of employees within the company (e.g., [46-48]) and gives them the opportunity to exercise their influence and pursue their sustainability-related targets. It is a channel and a means for them to direct their company toward certain sustainability goals. Therefore, participation enables employees to help improve a firm's SSPs, ESPs, and HRSPs. We assert that companies that foster higher levels of employee participation have higher levels of SSPs, ESPs, and HRSPs than companies that have a lower level of employee participation:

Hypothesis 1a. Employees' participation in decision making positively affects the level of a firm's SSPs.

Hypothesis 1b. Employees' participation in decision making positively affects the level of a firm's ESPs.

Hypothesis 1c. Employees' participation in decision making positively affects the level of a firm's HRSPs.

We also posit that OI moderates the relationship of participation and the three dimensions of sustainability. Employees' motivation to influence their firm's sustainability practices depends on the degree to which they identify themselves with the company. If they strongly identify with the company or derive a significant part of their social identity from the prestige of their company, they are more likely to exert a greater effort to make their company sustainable. Ashforth and Mael [33] indicate that reinforcement of the sources of identification, such as distinctiveness, prestige, and group salience, is based on the employees' level of identification: 'If people identify strongly with a group whose norms prescribe certain actions, then they are more likely to do those things than if they did not identify strongly'. Thus, we also propose the following: 
Hypothesis 2a. OI moderates the relationship of employees' participation and SSPs such that the relationship is stronger when OI is high than when it is low.

Hypothesis $\mathbf{2 b}$. OI moderates the relationship of employees' participation and ESPS such that the relationship is stronger when OI is high than when it is low.

Hypothesis 2c. OI moderates the relationship of employees' participation and HRSPs such that the relationship is stronger when OI is high than when it is low.

\section{Methods}

\subsection{Sample and Procedure}

We employed the survey method to collect the data, using a self-reported questionnaire completed by the employees of large companies dealing in fast-moving consumer goods. In line with Rupp et al. [23] and Farooq et al. [15,49], we defined employees as those within the lower-management and/or non-management workforce. We focused on this population, and excluded middle and top management, because our interest was in employees as a specific stakeholder group, as opposed to those directly developing and implementing formal CSR policy.

After seeking permission from the company, the authors visited the target companies and obtained the data face-to-face from the respondents. The questionnaire was accompanied by a cover letter. To control for social desirability bias, we emphasized anonymity and confidentiality both verbally and in the cover letter [50]. We obtained 448 responses, 27 of which we discarded because of missing values. The final sample comprised 421 employees.

We relied on a number of self-report measures, but primarily relying on self-report measures could lead to social desirability bias. To deal with this preemptively, we made multiple confidentiality assurances to our participants [50]. Moreover, we believe that self-reporting was most appropriate in the context of our study, in that many of our key variables involved perceptual constructs. That is, we sought to measures employees' perceptions of the firm's sustainability and their participation in decision making. In this sense, respondents themselves have the best insights as to their specific perceptions. Similar arguments have been made for identification, in that identification is viewed as an individual's cognitive precursor [51] and is less likely to be known by co-workers or supervisors.

\subsection{Measures}

To measure corporate sustainability, we relied on employees own perceptions. First, it is difficult to find data on Pakistani companies pertaining to the available sustainability indices. Second, it is the sustainability perception of the employees that influences their attitudes. These perceptions might be different from the actual level of sustainability [52]. Because sustainability researchers tend to heavily rely on indexes, there is a lack of self-report sustainability measures. We examined the CSR literature and found some available instruments, such as those of Maignan et al. [53], Aupperle [54], Farooq et al. [12] and Turker [55]. Of these instruments, Farooq et al.'s [14] instrument is the only one that corresponds to our operationalization of the sustainability construct. This instrument is a modified form of Turker [55]. It is based on a stakeholder framework and classifies CSR actions into three categories: CSR towards community, CSR towards environment, CSR towards employees. This classification is similar to our operationalization of corporate sustainability. We use three items pertaining to CSR towards community to measure SSPs, four items pertaining to CSR towards environment to measure the ESPs and six items pertaining to CSR towards employees to measure HRSPs.

To measure OI, we relied on a five-item revised version of Mael and Ashforth's [56] scale. This scale has shown good reliability $(>0.80)$ in previous work. We measure EPDM with a four-item scale from Delery and Doty [45], who report a Cronbach's alpha value of 0.80 . Li-Yun et al. [44] also use this scale in a Chinese context and report reasonably good reliability $(>0.70)$. EPDM is defined as the 
amount of influence that employees have over a company's decisions [43] or their opportunities to suggest improvements in the way things are done [44,45]. We consider the participation at all levels. High EPDM means that employees are given opportunities to participate in decsions related to their teams, department, and organizations.

We translated the instrument into Urdu, the national language of Pakistan, using a forwardbackward translation procedure [57]. We collected data using a Likert scale, where 1 = extremely disagree and 7 = extremely agree.

\subsection{Measurement Validity and Reliability}

To test the measurement validity of all the instruments, we conducted a confirmatory factor analysis (CFA) using structural equation modeling in AMOS. The CFA of the five variables (three dimensions of sustainability, identification, and employee participation) containing 21 items produced a good fit with the data. The chi-square $(\chi 2)$ statistic was 562.6, with a significance level of 0.001 and 198 degrees of freedom $(\chi 2 /$ d.f. $=2.84)$, thus indicating good fit [58]. The goodness-of-fit index (GFI) was 0.90 , which is equal to the generally accepted 0.90 level. We also examined incremental fit indices: the normed fit index (NFI) was 0.91, Bollen's incremental fit index (IFI) was 0.94, the Tucker-Lewis index (TLI) was 0.94, and the confirmatory fit index (CFI) was 0.94, which were all above the recommended level of 0.90 . In addition, the root mean square error of approximation (RMSEA) was 0.066 , which is also good because it is less than the threshold of 0.080 . In addition to model fit, we examine the standardized loadings of all the items on their respective factors. The standardized factor loadings for all items were between 0.67 and 0.89 . According to Kline [58], a standardized value higher than 0.60 on its respective factor demonstrates a reasonably high factor loading. In addition, we analyzed the convergent and discriminant validity of the five-factor measurement model using the average variance extracted (AVE) method [59]. The AVE values and squared correlations appear in Table 1. The AVE values of all the variables were greater than the recommended value of 0.50 [59], thus indicating high convergent validity of our instruments. To assess discriminant validity, we used a factor-based procedure, a powerful method that can resolve the problems of difference in chi-square methods [59]. The five variables differ from one another because the AVE of each dimension is greater than their squared correlations (Table 1). Thus, CFA indicates that our measurement instruments are valid and have adequate convergent and discriminant validity.

Table 1. Convergent and discriminant validity of instruments.

\begin{tabular}{ccccccc}
\hline Latent Variables & $\mathbf{1}$ & $\mathbf{2}$ & $\mathbf{3}$ & $\mathbf{4}$ & $\mathbf{5}$ & Alpha Reliability \\
\hline HRSPs & $\mathbf{0 . 6 1}$ & & & & & 0.91 \\
SSPs & 0.35 & $\mathbf{0 . 6 6}$ & & & & 0.85 \\
ESPs & 0.19 & 0.34 & $\mathbf{0 . 7 2}$ & & & 0.91 \\
EPDM & 0.22 & 0.31 & 0.10 & $\mathbf{0 . 6 6}$ & & 0.89 \\
OI & 0.19 & 0.18 & 0.12 & 0.24 & $\mathbf{0 . 6 0}$ & 0.88 \\
\hline
\end{tabular}

These scales have shown reasonable internal consistency and reliability in a Pakistani context; alpha values for all the variables are greater than the recommended value of 0.70 [60]. The alpha values of all the variables appear in the last column of Table 1.

\subsection{Common Method Variance}

The current study relies on the data collected using cross-sectional design that may cause the issue of common method variance [61,62]. Therefore, we performed many diagnostic tests to ensure there was not an issue of common method variance. We performed Harman's [63] one factor analysis by using the principle component analysis that produced five distinct factors which accounted for $73.34 \%$ variance as a whole and its first factor yielded only $20.18 \%$ variance. On the other hand, when all the factors were loaded to one factor it showed only $39.29 \%$ variance. We also compared the model fit indices of single-factor-CFA (all the factors loaded to common latent factor) with the 
five-factor-model, the results indicated that the fit indices of the five-factor-model $\left(X^{2}=562.60, X^{2} / \mathrm{Df}\right.$ $=2.84, \mathrm{GFI}=0.89, \mathrm{CFI}=0.94, \mathrm{RMSEA}=0.07)$ are better than the single-factor-model $\left(\mathrm{X}^{2}=3065.36\right.$, $\mathrm{X}^{2} / \mathrm{Df}=14.73, \mathrm{GFI}=0.53, \mathrm{CFI}=0.54, \mathrm{RMSEA}=0.18$ ). Finally, we performed the common latent factor analysis by applying the technique proposed by Gaskin [61]. The standardized regression weights of all the variables in the measurement model were calculated after adding the common latent factor, these scores were compared with the standardized regression weights of all the variables (without common latent factor). The findings showed that no factor had a difference more than 0.10 .

\section{Results}

\subsection{Descriptive Statistics}

Table 2 shows means, standard deviations, and correlations values. The correlation table shows all the hypothesized and non-hypothesized relationships among the variables. The three components of sustainability were positively correlated with one another. They were also positively related to employees' participation and OI. However, respondents' demographic characteristics were not related to three components of sustainability nor to participation and OI.

Table 2. Mean, standard deviation, correlations, and Cronbach's alpha values.

\begin{tabular}{cccccccc}
\hline Variables & Mean & St. Deviation & $\mathbf{1}$ & $\mathbf{2}$ & $\mathbf{3}$ & $\mathbf{4}$ & $\mathbf{5}$ \\
\hline HRSPs & 4.1 & 1.26 & 1 & & & & \\
SSPs & 3.65 & 1.33 & $0.59 *$ & 1 & & & \\
ESPs & 3.39 & 1.41 & $0.44^{*}$ & $0.58^{*}$ & 1 & & \\
EPDM & 4.81 & 1.07 & $0.47^{*}$ & $0.56^{*}$ & $0.30 *$ & 1 & \\
OI & 4.44 & 1.21 & $0.43^{*}$ & $0.42 *$ & $0.35^{*}$ & $0.49 *$ & 1 \\
\hline \multicolumn{7}{c}{$\mathrm{N}=421,{ }^{*} p<0.05}$.
\end{tabular}

\subsection{Hypotheses Testing}

We used structural equation modeling to test our model. We developed a structural regression model that enabled us to test all our hypotheses (direct effects and moderating effects) simultaneously. The model appears in Figure 2. This model produces a good fit with the data $(\chi 2=725.33$, d.f. $=218$, $\chi 2 /$ d.f. $=3.32 ; \mathrm{GFI}=0.89 ; \mathrm{NFI}=0.90 ; \mathrm{CFI}=0.93$; RMSEA $=0.07$ ). The results we obtained from this model appear in Table 3.

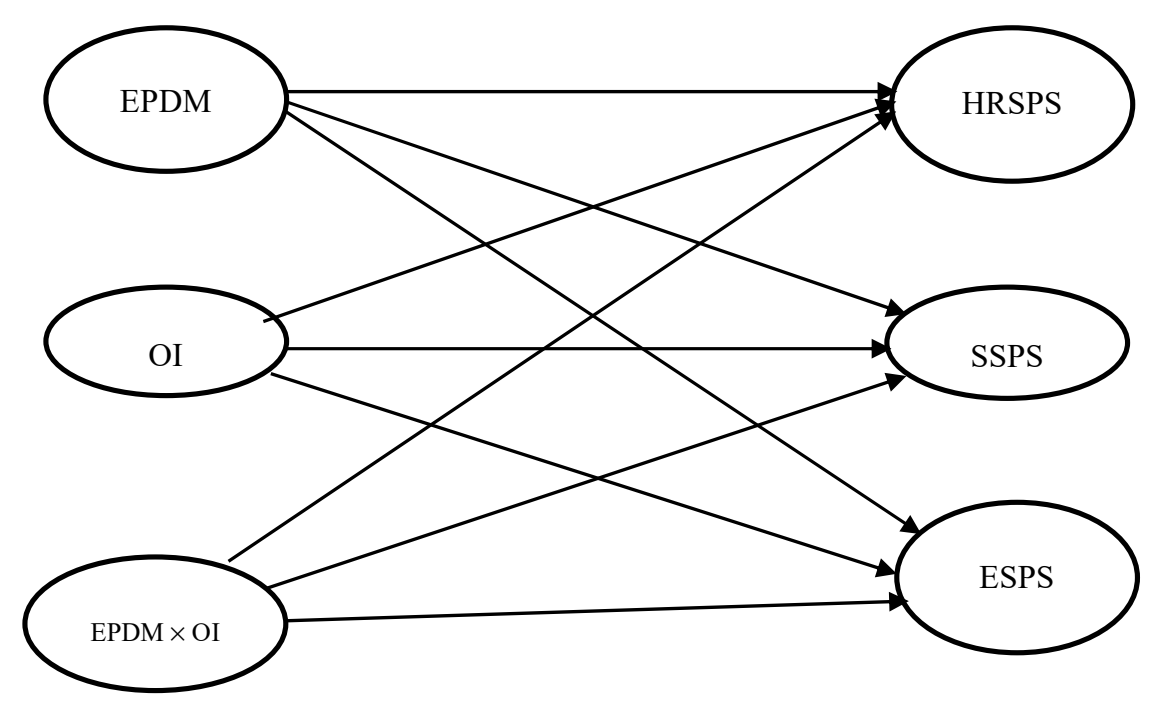

Figure 2. Structure regression model in AMOS for hypotheses testing. Notes: EPDM $\times$ OI is the product term of the interaction between these variables. For greater simplicity and clarity, we do not show covariances among independent variables, the item-level structure of the constructs, or error terms of dependent variables. 
Table 3. Direct effects of EPDM on three components of sustainability and the moderated effect of OI.

\begin{tabular}{cccc}
\hline & \multicolumn{3}{c}{ Dependent Variables } \\
\hline Independent Variables & HRSPs & SSPs & ESPs \\
\hline EPDM & $0.34^{* * *}$ & $0.44^{* * *}$ & $0.21^{* * *}$ \\
OI & $0.33^{* * *}$ & $0.28^{* * *}$ & $0.29^{* * *}$ \\
EPDM $\times$ OI (interaction term) & $0.12^{* *}$ & $0.14^{* *}$ & 0.04
\end{tabular}

Notes: The cell values are standardized regression weights. EPDM $\times$ OI represents the interaction term of EPDM and OI. ${ }^{* *}$ Significant at $0.01 .{ }^{* * *}$ Significant at 0.001 .

The data support Hypotheses $1 \mathrm{a}, 1 \mathrm{~b}$, and 1c (see Table 3$)$. There was a positive effect $\left(0.34^{* * *}\right)$ of EPDM on HRSPs at a 0.001 significance level. Similarly, EPDM had a strong positive effect $\left(0.44^{* * *}\right)$ on SSPs and a moderate positive influence $\left(0.21^{* * *}\right)$ on ESPs at a 0.001 significance level. The comparative analysis of the standardized regression weights suggests that EPMD had the strongest influence on SSPs and the least influence on ESPs.

The data also support Hypotheses 2a and 2c, but not Hypothesis 2b. Hypothesis 2a demonstrates that OI moderates the relationship of employee participation and SSPs such that the relationship is stronger when OI is high than when it is low. The interaction term was significant at 0.05. We show this moderating effect of OI on the relationship between EPDM and SSPs in Figure 3.

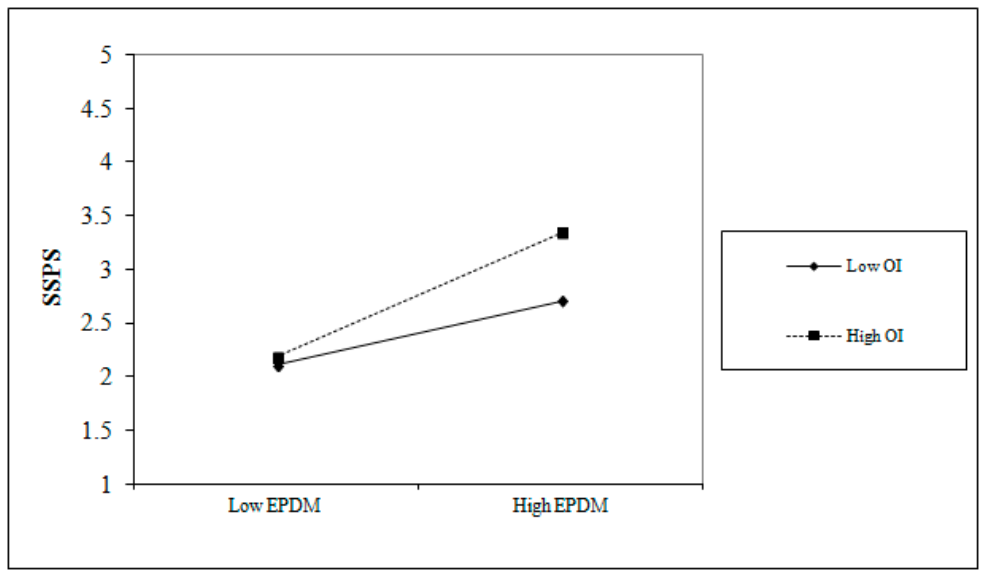

Figure 3. Moderation of OI on the EPDM-SSPS relationship.

Similarly, we found that OI positively moderated the effect of EPDM on HRSPs (at a 0.01 significance level) such that the relationship is stronger when OI is high than when it is low. Therefore, the data support Hypothesis 2c. Figure 4 shows this moderating effect.

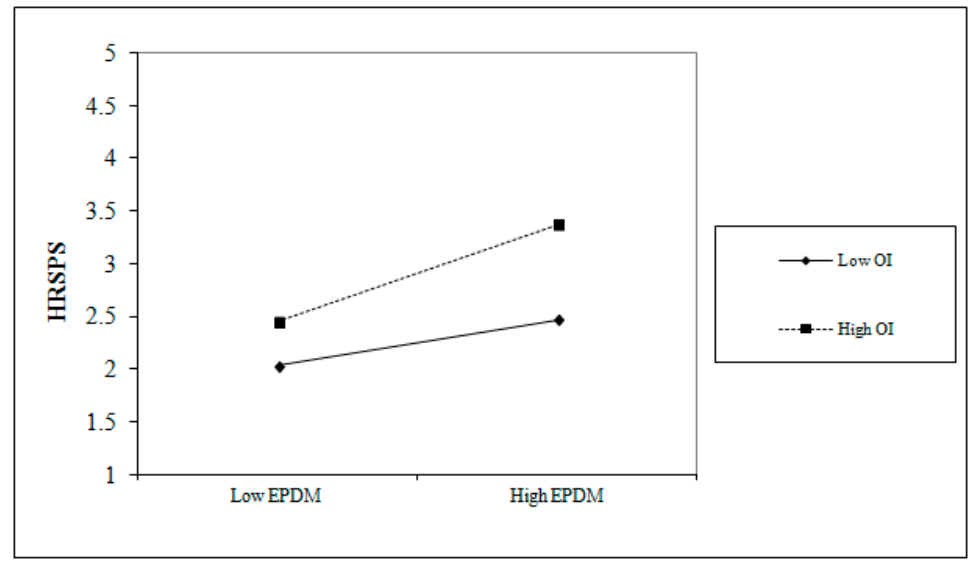

Figure 4. Moderation of OI on the EPDM-HRSPS relationship. 
In contrast, the moderating effect of OI on the relationship between EPDM and ESPs was not significant. Thus, the data do not support Hypothesis $2 b$ (see Table 3) and Figure 5.

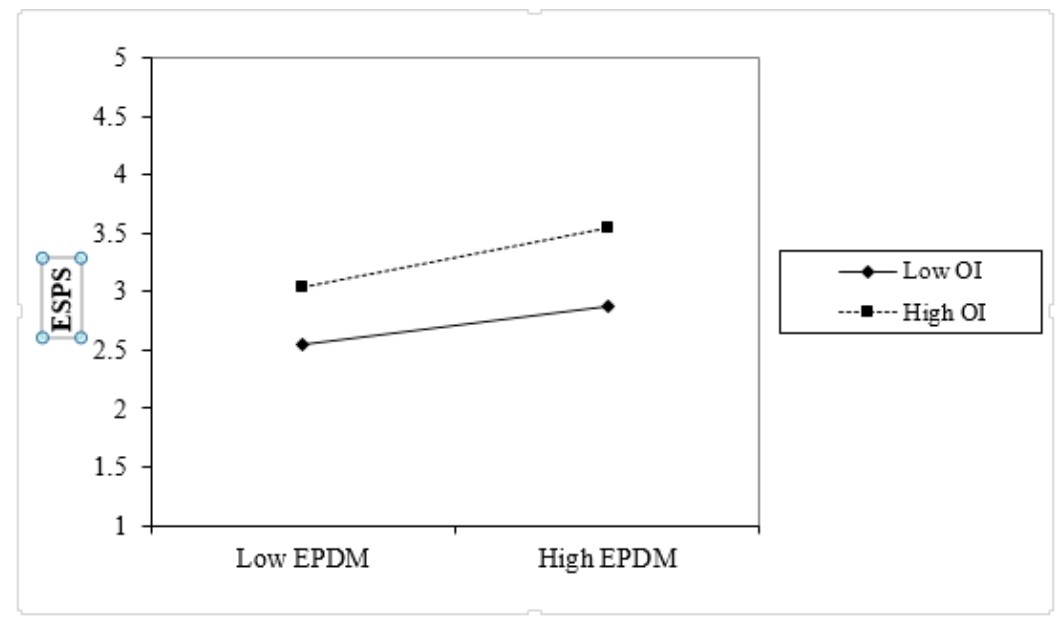

Figure 5. Moderation of OI on the EPDM-HRSPS relationship.

\section{Discussion}

In this research, conducted in South Asian organizations, we identified an HR practice that is essential for corporate sustainability. Specifically, the main objective of the research was to examine the role of employees' participation and OI in firms' corporate sustainability performance.

Our findings reveal the positive role of employees' participation in the sustainability performance of the firm. We found that employees' participation has a strong positive effect on all three components of sustainability. Thus, we can conclude that by increasing employees' participation in decision making, firms can increase their sustainability level. These results show that HR practices are not only important for firm productivity and financial performance but also central to the firm's sustainability performance. Furthermore, HR practices play an important role in achieving organizational goals, regardless of whether these goals are financial performance or sustainability.

The results also confirm our theoretical framework, which we based on social identity theory. The study validates the proposition that social identity reinforces its antecedents, especially those related to corporate sustainability, such as SSPs, ESPs, and HRSPs. We assert that employees are conscious of and sensitive to issues related to the sustainability status of their organization, and this motivates them to exert effort within the organization to strengthen their distinctive and prestigious sustainability image. The results also confirm the proposition that participation increases employees' influence within the company (e.g., $[43,46,48])$, and they can express their opinions and pursue their sustainability-related interests through this process.

We can also explain these findings from the perspective of the HR and organizational behavior literature [64,65], which suggest that employee participation enhances the flow and use of knowledge and important information in organizations because employees usually have more knowledge and information about their work than managers. Therefore, employee participation enables the firm to make decisions with better information. Melcher [66] asserts that participation not only results in better decisions but also ensures better implementation because employees know more about implementing work procedures after decisions have been made. Consequently, these firms have higher productivity, increased overall quality, and decreased costs [67], which are also consistent with the core values of a firm's sustainability performance [2].

The results also show that OI moderates the relationship between participation and sustainability components. Specifically, the effect of participation is stronger when OI is high than when it is low. This implies that employees' motivation to influence their firm to enhance its sustainability performance depends on the degree to which the employees identify themselves with the company. If they strongly 
identify with the company or derive a significant part of their social identity from the sustainability prestige of their company, they may exert greater effort to make their company more sustainable. However, this may not be the case for a firm's ESPs, because OI does not moderate the effect of participation on the firm's environmental sustainability performance. These findings are supported by Farooq, Farooq and Jasimuddin [14], who showed that environmental-related CSR activities do not significantly affect the employees' identification with their company. As employees do not derive a significant part of their social identity from ESPs, OI does not moderate the effect of employees' participation in such practices.

\subsection{Theoretical Implications}

This research presents an interdisciplinary framework insofar as we applied a social psychological theory to understand an organizational phenomenon. This paper also integrates the macro-level concept of sustainability with micro-level variables related to employees.

This research has significant implications for the sustainability and HR literature. The finding that employee participation plays an important role in enhancing the sustainability level of the firm opens a new line of discourse in both the corporate sustainability literature as well as HR research. This research also underscores the role of employee participation in a very different field. Conventional research on participation focuses on understanding its effects on the employees' behaviors, whereas the current study examines its effects on firms' behaviors (i.e., sustainability practices). Thus, this research offers a different lens through which to examine employee participation.

This research also has implications for the social identity literature. For example, we confirm the proposition that social identity reinforces its antecedents, and these findings hold appeal for scholars examining factors that drive group behaviors. Finally, as we discussed previously, this study has a unique contextual contribution because it is conducted in South Asia.

\subsection{Practical Implications}

The results have significant implications for firms' sustainability strategies, offering strategic guidelines to managers in their struggle to enhance the sustainability level of their firm. The results underscore the importance of employee participation in pursuing a sustainability strategy. In addition, HR managers should recognize that participation has multifaceted benefits for the firm. Not only does it build cooperation between managerial and nonmanagerial employees, create a positive workplace culture, promote information sharing, and enhance productivity and adaptability $[43,46,48,68,69]$, it also helps the firm achieve its sustainability goals. This study also suggests the need to foster employees' OI to better achieve the firm's goals.

\subsection{Limitations and Future Research Directions}

This research has several limitations. Conceptually, we did not consider all three bottom lines of sustainability; rather, we restricted the work to the people and planet dimensions. Future studies could include the bottom line of profitability to examine whether employees draw their social identity from it. It would also be worthwhile exploring the effect of employee participation on the third bottom line. In addition, we only examined the impact of participation and identification on firm sustainability, but we believe that identification not only compels employees to direct the behavior of the firm but also drives the behavior of the employees themselves toward the sustainability goals. Thus, future studies that explore the effects of OI on employees' sustainability behavior might provide noteworthy results.

Methodologically, we used a convenience sampling method for data collection; thus, the sample may not be truly representative of the population. In addition, data on all the variables were collected from a single source, which may cause common method bias. However, we used multiple methods to test for common method bias, and the results suggest that common method bias was not a serious threat. Finally, the data reported in this study were collected at one point in time, making it impossible to draw inferences of causality [70]. 
Author Contributions: Formal analysis, O.F. and M.F.; Funding acquisition, O.F.; Investigation, M.F.; Methodology, M.F.; Project administration, O.F.; Supervision, E.R.; Writing-original draft, O.F.; Writing-review \& editing, O.F., M.F. and E.R.

Funding: This research is partially supported by UAE University, Al Ain-UAE via the Startup grant to first author.

Conflicts of Interest: The authors declare no conflict of interest.

\section{References}

1. Elkington, J. Cannibals with Forks: The Triple Bottom Line of 21st Century Business; Capstone Publishing Ltd.: Oxford, UK, 1997; Available online: http:/ / appli6.hec.fr/amo/Public/Files/Docs/148_en.pdf (accessed on 25 October 2018).

2. Hart, S.L.; Milstein, M.B.; Caggiano, J. Creating sustainable value [and Executive Commentary]. Acad. Manag. Exec. (1993-2005) 2003, 17, 56-69.

3. Bansal, P. Evolving sustainably: A longitudinal study of corporate sustainable development. Strat. Manag. J. 2005, 26, 197-218. [CrossRef]

4. Fowler, S.J.; Hope, C. Incorporating sustainable business practices into company strategy. Bus. Strat. Environ. 2007, 16, 26-38. [CrossRef]

5. Shrivastava, P. Environmental technologies and competitive advantage. Strat. Manag. J. 1995, 16, $183-200$. [CrossRef]

6. Shrivastava, P.; Hart, S. Creating sustainable corporations. Bus. Strat. Environ. 1995, 4, 154-165. [CrossRef]

7. Ehnert, I. Sustainable Human Resource Management: A Conceptual and Exploratory Analysis from a Paradox Perspective; Springer: Berlin, Germany, 2009.

8. Boudreau, J.W.; Ramstad, P.M. Talentship, talent segmentation, and sustainability: A new HR decision science paradigm for a new strategy definition. Hum. Resour. Manag. 2005, 44, 129-136. [CrossRef]

9. Becker, B.E.; Huselid, M.A. High performance work systems and firm performance: A synthesis of research and managerial implications. Res. Pers. Hum. Resour. Manag. 1998, 16, 53-101.

10. Guthrie, J.P. High-involvement work practices, turnover, and productivity: Evidence from New Zealand. Acad. Manag. J. 2001, 44, 180-190.

11. Ramus, C.A.; Steger, U. The roles of supervisory support behaviors and environmental policy in employee "Ecoinitiatives" at leading-edge European companies. Acad. Manag. J. 2000, 43, 605-626.

12. Farooq, O.; Payaud, M.; Merunka, D.; Valette-Florence, P. The impact of corporate social responsibility on organizational commitment: Exploring multiple mediation mechanisms. J. Bus. Ethics 2013, 125, 563-580. [CrossRef]

13. Kim, H.R.; Lee, M.; Lee, H.T.; Kim, N.M. Corporate social responsibility and employee-company identification. J. Bus. Ethics 2010, 95, 557-569. [CrossRef]

14. Farooq, M.; Farooq, O.; Jasimuddin, S.M. Employees response to corporate social responsibility: Exploring the role of employees' collectivist orientation. Eur. Manag. J. 2014, 32, 916-927. [CrossRef]

15. Farooq, O.; Rupp, D.E.; Farooq, M. The multiple pathways through which internal and external corporate social responsibility influence organizational identification and multifoci outcomes: The moderating role of cultural and social orientations. Acad. Manag. J. 2017, 60, 954-985. [CrossRef]

16. De Roeck, K.; Farooq, O. Corporate social responsibility and ethical leadership: Investigating their interactive effect on employees' socially responsible behaviors. J. Bus. Ethics 2018, 151, 923-939. [CrossRef]

17. Jones, D.A.; Rupp, D.E. Social responsibility in and of organizations: The psychology of corporate social responsibility among organizational members. In Handbook of Industrial, Work, and Organizational Psychology, 2nd ed.; Andersons, N., Ones, D.S., Sinangil, H.K., Viswesvaran, C., Eds.; Sage: Thousand Oaks, CA, USA, 2016.

18. Khatri, N.; Fern, C.T.; Budhwar, P. Explaining employee turnover in an Asian context. Hum. Resour. Manag. J. 2001, 11, 54-74. [CrossRef]

19. Hogg, M.A. Social identity theory. In Contemporary Social Psychological Theories; Burke, P.J., Ed.; Stanford University Press: Palo Alto, CA, USA, 2006; pp. 111-136.

20. Van Marrewijk, M.; Werre, M. Multiple levels of corporate sustainability. J. Bus. Ethics 2003, 44, 107-119. [CrossRef] 
21. Aras, G.; Crowther, D. Governance and sustainability: An investigation into the relationship between corporate governance and corporate sustainability. Manag. Decis. 2008, 46, 433-448. [CrossRef]

22. Jamali, D. Insights into triple bottom line integration from a learning organization perspective. Bus. Process. Manag. J. 2006, 12, 809-821. [CrossRef]

23. Rupp, D.E.; Ganapathi, J.; Aguilera, R.V.; Williams, C.A. Employee reactions to corporate social responsibility: An organizational justice framework. J. Organ. Behav. Int. J. Ind. Occup. Organ. Psychol. Behav. 2006, 27, 537-543. [CrossRef]

24. Dyllick, T.; Hockerts, K. Beyond the business case for corporate sustainability. Bus. Strat. Environ. 2002, 11, 130-141. [CrossRef]

25. Spangenberg, J.H. Reconciling sustainability and growth: Criteria, indicators, policies. Sustain. Dev. 2004, 12, 74-86. [CrossRef]

26. Matten, D.; Moon, J. "Implicit" and "explicit" CSR: A conceptual framework for a comparative understanding of corporate social responsibility. Acad. Manag. Rev. 2008, 33, 404-424. [CrossRef]

27. McWilliams, A.; Siegel, D. Corporate social responsibility: A theory of the firm perspective. Acad. Manag. Rev. 2001, 26, 117-127. [CrossRef]

28. Rego, A.; Leal, S.; Cunha, M.; Faria, J.; Pinho, C. How the perceptions of five dimensions of corporate citizenship and their inter-inconsistencies predict affective commitment. J. Bus. Ethics 2010, 94, 107-127. [CrossRef]

29. Aragón-Correa, J.A. Strategic proactivity and firm approach to the natural environment. Acad. Manag. J. 1998, 41, 556-567. [CrossRef]

30. Clarkson, M.B.E. A stakeholder framework for analyzing and evaluating corporate social performance. Acad. Manag. Rev. 1995, 20, 92-117. [CrossRef]

31. Carroll, A.B. A three-dimensional conceptual model of corporate performance. Acad. Manag. Rev. 1979, 4, 497-505. [CrossRef]

32. Aberson, C.L.; Healy, M.; Romero, V. Ingroup bias and self-esteem: A meta-analysis. Personal. Soc. Psychol. Rev. 2000, 4, 157-173. [CrossRef]

33. Ashforth, B.E.; Mael, F. Social identity theory and the organization. Acad. Manag. Rev. 1989, 14, 20-39. [CrossRef]

34. Tajfel, H.; Turner, J.C. The social identity theory of group behavior. In Psychology of Intergroup Relations; Tajfel, H., Ed.; Cambridge University Press: Cambridge, UK, 1985.

35. Hogg, M.A.; Terry, D.J. Social identity and self-categorization processes in organizational contexts. Acad. Manag. Rev. 2000, 25, 121-140. [CrossRef]

36. Mael, F.; Ashforth, B.E. Alumni and their alma mater: A partial test of the reformulated model of organizational identification. J. Organ. Behav. 1992, 13, 103-123. [CrossRef]

37. Tyler, T.R. Why people cooperate with organizations: An identity-based perspective. Res. Organ. Behav. 1999, 21, 201-246.

38. Rowley, T.I.; Moldoveanu, M. When will stakeholder groups act? An interest-and identity-based model of stakeholder group mobilization. Acad. Manag. Rev. 2003, 28, 204-219. [CrossRef]

39. Terry, D.J.; Hogg, M.A. Group norms and the attitude-behavior Relationship: A role for group identification. Person. Soc. Psychol. Bull. 1996, 22, 776-793. [CrossRef]

40. Brammer, S.J.; Millington, A.I. Corporate reputation and philanthropy: An empirical analysis. J. Bus. Ethics 2005, 61, 29-44. [CrossRef]

41. Fombrun, C.; Shanley, M. What's in a name? Reputation building and corporate strategy. Acad. Manag. J. 1990, 33, 233-258.

42. Fryxell, G.E.; Jia, W. The fortune corporate 'reputation index': Reputation for what? J. Manag. 1994, 20 , 1-14. [CrossRef]

43. Long, R.J. The Effects of Employee Ownership on Job Attitudes and Organizational Performance: An Exploratory Study. doctoral dissertation. Ph.D. Thesis, Cornell University, Ithaca, NY, USA, 1978.

44. Li-Yun, S.U.N.; Aryee, S.; Law, K.S. High-performance human resource practices, citizenship behavior, and organizational performance: A relational perspective. Acad. Manag. J. 2007, 50, 558-577.

45. Delery, J.E.; Doty, D.H. Modes of theorizing in strategic human resource management: Tests of universalistic, contingency, and configurational performance predictions. Acad. Manag. J. 1996, 39, 802-835. [CrossRef] 
46. Argyris, C. Analysis of the Human Relations Policies and Practices in England, Norway, Holland, France, Greece and Germany; OECD Department of Management Reports: Paris, France, 1955.

47. Long, R.J. The effects of employee ownership on organizational identification, employee job attitudes, and organizational performance: A tentative framework and empirical findings. Hum. Relat. 1978, 31, $29-48$. [CrossRef]

48. Tannenbaum, A.S. Social Psychology of the Work Organization; Tavistock: London, UK, 1966.

49. Farooq, O.; Merunka, D.; Valette-Florence, P. Employees' response to corporate social responsibility: An application of a non linear mixture REBUS approach. In New Perspectives in Partial Least Squares and Related Methods; Abdi, H., Chin, W.W., Vinzi, V.E., Russolillo, G., Trinchera, L.B., Eds.; Springer: Berlin, Germany, 2013; pp. 257-268.

50. Chung, J.; Monroe, G.S. Exploring social desirability bias. J. Bus. Ethics 2003, 44, 291-302. [CrossRef]

51. Pratt, M.G. To be or Not to Be? Central questions in organizational identification. In Central Questions in Organizational Identification; Sage: Thousand Oaks, CA, USA, 1998; pp. 171-207.

52. Peterson, D.K. The relationship between perceptions of corporate citizenship and organizational commitment. Bus. Soc. 2004, 43, 296-319. [CrossRef]

53. Maignan, I.; Ferrell, O.C.; Hult, G.T.M. Corporate citizenship: Cultural antecedents and business benefits. J. Acad. Mark. Sci. 1999, 27, 455-469. [CrossRef]

54. Aupperle, K.E. An Empirical Inquiry into the Social Responsibilities as Defined by Corporations: An Examination of Various Models and Relationships. Ph.D. Thesis, University of Georgia, Athens, GA, USA, 1982.

55. Turker, D. How corporate social responsibility influences organizational commitment. J. Bus. Ethics 2009, 89, 189-204. [CrossRef]

56. Mael, F.; Ashforth, B.E. Loyal from day one: Biodata, organizational identification, and turnover among newcomers. Person. Psychol. 1995, 48, 309-333. [CrossRef]

57. Brislin, R.W. Translation and content analysis of oral and written material. Methodology. 1980, 2, 389-444.

58. Kline, R.B. Principles and Practice of Structural Equation Modeling, (Methodology in the Social Sciences); Guilford Press: New York, NY, USA, 2004.

59. Fornell, C.; Larcker, D.F. Structural equation models with unobservable variables and measurement error: Algebra and statistics. J. Mark. Res. 1981, 18, 382-388. [CrossRef]

60. Nunnally, J.C. Psychometric Theory, 2nd ed.; McGraw-Hill: New York, NY, USA, 1978.

61. Gaskin, J. Common Method Bias Using Common Latent Factor. Available online: https://youtu.be/ Y7Le5Vb7_jg (accessed on 14 February 2018).

62. Podsakoff, P.M.; MacKenzie, S.B.; Lee, J.-Y.; Podsakoff, N.P. Common method biases in behavioral research: A critical review of the literature and recommended remedies. J. Appl. Psychol. 2003, 88, 879-903. [CrossRef]

63. Harman, H.H. Modern Factor Analysis; University of Csection Chicago Press: Chicago, IL, USA, 1960.

64. Anthony, W.P. Participative Management, Reading, Mass; Addison-Wesley: Boston, MA, USA, 1978.

65. Frost, C.F.; Wakeley, J.H.; Ruh, R.A. The Scanlon Plan for Organization Development: Identity, Participation, and Equity; Michigan State University Press: East Lansing, MI, USA, 1996.

66. Melcher, A.J. Participation: A critical review of research findings. Hum. Resour. Manag. 1976, 15, $12-21$. [CrossRef]

67. Cotton, J.L.; Vollrath, D.A.; Froggatt, K.L.; Lengnick-Hall, M.L.; Jennings, K.R. Employee participation: Diverse forms and different outcomes. Acad. Manag. Rev. 1988, 13, 8-22. [CrossRef]

68. Coyle-Shapiro, J.A.M. Changing employee attitudes. J. Appl. Behav. Sci. 2002, 38, 57-77. [CrossRef]

69. Katz, D.; Kahn, R.L. The Social Psychology of Organizations; Wiley: New York, NY, USA, 1978.

70. Kuvaas, B. Performance appraisal satisfaction and employee outcomes: Mediating and moderating roles of work motivation. Int. J. Hum. Resour. Manag. 2006, 17, 504-522. [CrossRef]

(C) 2019 by the authors. Licensee MDPI, Basel, Switzerland. This article is an open access article distributed under the terms and conditions of the Creative Commons Attribution (CC BY) license (http://creativecommons.org/licenses/by/4.0/). 